\title{
EL COMISARIO DE GUERRA EN NUEVA ESPAÑA (1727-1816): ANTECEDENTES Y DESARROLLO INSTITUCIONAL DE UNA FIGURA INSERTA EN EL CONTROL DEL GASTO MILITAR
}

\author{
THE WAR COMMISSIONER IN NEW SPAIN \\ (1727-1816): BACKGROUND AND INSTITUTIONAL \\ DEVELOPMENT OF A FIGURE INSERTED IN THE \\ CONTROL OF MILITARY SPENDING
}

\author{
ERnest SÁNChez SANTIRó \\ Instituto de Investigaciones Dr. José María Luis Mora, México \\ esanchez@institutomora.edu.mx
}

https://doi.org/10.36105/iut.2021n33.02

Recibido: 03/08/2021

Aceptado: 30/08/2021

\section{RESUMEN}

El trabajo analiza los antecedentes y el diseño institucional de una figura cuyo principal cometido fue coadyuvar al control del gasto militar, en especial el prest (salario) de la tropa y los sueldos de la oficialidad del ejército virreinal: los comisarios de guerra. Se muestra su origen y transformación a lo largo del siglo XVIII.

Palabras clave:

Real Hacienda, gasto militar, comisario de guerra, Nueva España, siglo XVIII. Abstract:

This paper analyzes the background and institutional design of a figure whose main task was to contribute to the control of military spending, especially 
the most extensive, which was the salary of the troops and the officers of the vice royal Army: the war commissioners. Its origin and transformation throughout the 18th century are shown.

\section{Keywords:}

Royal Treasury, military expenditure, war commissary, New Spain, 18th century.

\section{INTRODUCCIÓN}

El conocimiento historiográfico en torno al desarrollo del Ejército virreinal ha experimentado un notable crecimiento en los últimos años. Contamos ya con trabajos generales sobre la expansión, que no creación, del ejército en las Indias desde la década de 1760, un fenómeno que conjugó el arribo de importantes contingentes de tropa veterana transferidos desde España, acompañados del levantamiento de batallones provinciales en América, ${ }^{1}$ así como la plasmación de estos fenómenos en Nueva España. ${ }^{2}$ Sobre esta base se han ido dilucidando cuestiones diversas, de entre las que destacamos la presencia creciente de los cuerpos armados en el territorio, la expansión del número de efectivos o la elevación del costo que representaron estos hechos para el Erario Regio novohispano. ${ }^{3}$

Por otra parte, la historiográfica ha evidenciado la creciente "militarización"4 acaecida en Nueva España con motivo de los diversos conflictos internacionales en los que se vio envuelta la Monarquía hispánica en el siglo XVIII: de apenas unos 4,100 efectivos a mediados del siglo XVIII se pasó a más de 31,000 a principios del siglo XIX. También se conocen mejor los problemas que enfrentó la Real Hacienda para enfrentar un costo cada vez más gravoso para el Erario Regio. Así, en el quinquenio de 1744-1748, el gasto de guerra en Nueva España ascendió a poco más de 2.3 millones de pesos, mientras que en el de 1795-1799 rondaba los 4.6 millones de pesos; un esfuerzo redoblado que apenas es una faceta de los problemas que generó esta expansión del gasto bélico, habiendo otros como, por ejemplo, los logísticos o los de control hacendario sobre dicha erogación. ${ }^{5}$ En este sentido, la constatación historiográfica del incremento del gasto de guerra no ha sido acompañada por estudios específicos que atiendan a la complejidad administrativa y de control del gasto que debieron representar estas realidades para

\footnotetext{
ALBI, Julio, La defensa de las Indias, 1987.

Al respecto, la obra clásica sería: ARCHER, Christon I., The Army in Bourbon Mexico, 1977.

ArCHER, Christon I., The Army in Bourbon Mexico, 1977; KLEIN, Herbert S., Las finanzas americanas, 1994, pp. 129-132; Ortiz Escamilla, Juan, Guerra y gobierno, 2014; SÁnChez SANTIRó, Ernest, "El gasto público", 2015.

4 En la historiografía el término alude a varios fenómenos, aquí lo adoptamos como una mera descripción del fenómeno del crecimiento cuantitativo del ejército. Rabinovich, Alejandro, "La militarización del Río de la Plata”, 2012.

5 No incluimos aquí el pago de situados externos. ARCHER, Christon I., "Bourbon Finances", 1981; SÁNCHEZ SANTIRó, Ernest, Corte de caja, 2013, pp. 235-237 y La imperiosa necesidad, 2016, pp. 136-140.
} 
los ministros y oficiales de la Real Hacienda, en el marco de un fenómeno todavía escasamente estudiado, como fue el del desarrollo de una Hacienda militar dotada de una creciente autonomía respecto del Erario Regio novohispano. Un fenómeno que cobró impulso en la última década del siglo XVIII, con motivo de los primeros acantonamientos de tropas en Nueva España. ${ }^{6}$

Con base en esta constatación, el propósito del presente trabajo es el estudio de los antecedentes y el diseño institucional de una figura cuyo principal cometido fue el coadyuvar al control del gasto militar, en especial, el prest (salario) de la tropa y los sueldos de la oficialidad del ejército virreinal: los comisarios de guerra. Sobre ellos, apenas tenemos un conocimiento muy somero y acotado en el tiempo, ya que la mayoría de los trabajos remiten al periodo de la guerra civil novohispana, con la oficina de la Comisaría General de Guerra, creada en 1817, como punto nodal. ${ }^{7}$ Lo que pretendemos rastrear, de manera incipiente y prospectiva, es el origen de los comisarios de guerra y cómo se fueron perfilando en el marco de la Real Hacienda de Nueva España. Para ello, el texto arranca con una sección en la que se caracteriza la figura del comisario de guerra, en el contexto de la reformulación del ejército acaecida con motivo de la guerra de Sucesión Española; continúa con el estudio del traslado de esta figura y funciones a Nueva España en un arco temporal que abarca desde la década de 1720 hasta la ordenanza de intendentes de 1786, para finalizar con el impacto de los acantonamientos de tropas acaecidos con motivo de las guerras que entabló la Monarquía hispánica contra Gran Bretaña, a partir de 1796, seguido de una breve noticia de lo ocurrido con los comisarios de guerra al inicio de la contienda civil en Nueva España, cerrando nuestro trabajo en la antesala de la Comisaría General de Guerra (1817), sobre la cual, como dijimos, contamos con mayor información en la historiografía.

\section{LA IRRUPCIÓN DEL COMISARIO DE GUERRA EN EL EJÉRCITO ESPAÑOL DE LOS BORBONES (1705-1758)}

Aunque la figura del comisario al servicio de la corona (un comisionado encargado de tareas específicas que, en ocasiones, podía estar dotado incluso de una ordenanza o reglamento ad hoc, sin detentar por esto un oficio permanente) es posible rastrearla en los reinos de la Monarquía católica al menos desde el siglo XVI, esta voz no hizo su entrada en el Diccionario de la lengua de la Real Academia hasta su edición de 1780. En ella encontramos las voces "comisaría" y "comisario". Por la primera se denominaba simplemente "el empleo de comisario", mientras que por "comisario" aparecía una definición más sustanciosa, dado que remitía a aquel "que tiene poder o facultad de otro para ejecutar alguna orden o entender en algún negocio". ${ }^{8}$ Nos hallamos pues ante una delegación de

\footnotetext{
6 Archer, Christon I., The Army in Bourbon Mexico, 1977.

7 Ortiz Escamilla, Juan, Guerra y gobierno, 2014, pp. 218-219; Sánchez Santiró, Ernest, “Antonio de Medina y Miranda", 2014 y La imperiosa necesidad, 2016, pp. 120-122.

8 Real Academia de la Lengua, Diccionario de la lengua, 1780, p. 246.
} 
funciones por parte de la autoridad, que no derivaba necesariamente de la posesión y ejercicio de un oficio como persona pública, ${ }^{9}$ que por lo general se ejercía de manera permanente, sino el mero desempeño de un cometido con un propósito determinado acotado en el tiempo.

Dicha caracterización no era extraña a la esfera hacendaria, en la medida en que la figura del comisario había sido uno de los instrumentos introducidos en diversos erarios regios europeos de la época moderna para el logro de determinados objetivos (v.g. vigilancia, eficiencia, logro de información, etc.), en general, y del hispano, en particular. ${ }^{10}$ En este marco, dedicamos los siguientes apartados al estudio del surgimiento de una modalidad específica de comisionados: los comisarios de guerra.

En el marco de la guerra de Sucesión Española, el ejército de Felipe V experimentó en 1704 una transformación radical en su estructura organizativa: del tercio como cuerpo de combate básico se pasó a un ejército basado en regimientos; unidades militares menos numerosas: de los 3,000 hombres previstos en cada tercio, según las ordenanzas de 1632, se pasó en 1704 a regimientos de 600 hombres, subdivididos a su vez en batallones. Un contingente que dos años después se duplicaría para alcanzar los 1,200 efectivos. ${ }^{11}$ Sin embargo, a efectos del presente trabajo nos interesa destacar otro trazo, a saber: el cambio organizativo de los cuerpos castrenses de tierra vino acompañado de la promulgación en 1705 de unas ordenanzas específicas para el control de dichos regimientos, merced a la Real ordenanza de 28 de julio de 1705 para la formalidad de las revistas que los comisarios de guerra han de pasar a las tropas: equipajes, tren de artillería y víveres de los ejércitos, como también de lo que se ha de observar por los tesoreros y asentistas de pan y cebada. ${ }^{12}$ En esta norma se despliega un modelo de control sobre los nuevos contingentes militares a partir de la figura de los comisarios de guerra. Veámoslo.

La ordenanza arrancaba con un propósito del monarca: "que mis tropas de infantería, caballería y dragones estén en adelante pagadas de sueldos, y asistidas

9 Para la distinción entre persona pública y privada, consultar: GARRIGA, Carlos, "Sobre el gobierno de la justicia", 2006, pp. 81-82.

10 Pietschmann, Horst, Las reformas borbónicas, 1996; Bertrand, Michel, Grandeza y miseria, 2011. Con este enfoque destaca el análisis realizado por Yovana Celaya sobre la comisión recibida por Juan Joseph de Veytia a finales del siglo XVII para la gestión de las alcabalas de la ciudad de Puebla (CelayA Nández, Yovana, Alcabalas y situados, 2010) o de Luis Jáuregui, sobre los intendentes novohispanos y su tránsito a los comisarios de la primera República Federal (JÁuregui, Luis, La Real Hacienda, 1999 y "Del intendente al comisario", 2001).

11 Gómez Ruiz, Manuel y Juanola, Vicente Alonso, El ejército de los Borbones, 1989; Borreguero Beltrán, Cristina, "Del tercio al regimiento", 2001. Para una valoración sobre las reformas militares de la nueva dinastía, consultar: ANDÚJAR CASTILlo, Francisco, "El reformismo militar", 2016. Para los cambios previos en la estructura militar, con el caso de Flandes como precedente destacado, ver: GLESENER, Thomas, L'empire des exilés, 2017. Para la conexión entre este cambio militar y el control contable basado, entre otros aspectos, en las revistas que debían elaborar los comisarios de guerra, consultar: DuBEt, Anne, Un estadista francés, 2008 (cap. VII).

12 Portugués, Joseph Antonio, Colección general, tomo X, 1765, pp. 327-341. TeiJeIro DE LA Rosa, Juan Miguel, "La Real Hacienda”, 2003, pp. 86-89. 
en todo con mayor puntualidad que antes", ${ }^{13}$ para lo cual se consideraba que el medio más adecuado a tal efecto era que...

[...] se pasen regularmente muestra ${ }^{14}$ cada mes a cada Regimiento, en cualquiera parte que se halle, y que en conformidad a ellas se pague por los tesoreros, quitando el embarazo de las muchas formalidades, que retardan los socorros, y ocasionan los grandes atrasos con que se hallan. ${ }^{15}$

Es decir, la muestra mensual, entendida como el pase periódico de revista de los regimientos, era el procedimiento que se vislumbraba para el buen pago del ejército borbónico. A la luz de la propuesta cabe preguntarse por la raíz del problema.

Además del problema crónico de fondos para hacer frente al pago del prest de la tropa y los sueldos de los oficiales de los regimientos, un problema crucial, en el contexto de la guerra que se estaba librando, se hallaba también la manera de determinar el monto específico que debía recibir cada regimiento. Las ordenanzas militares generales, en conjunción con las específicas de cada cuerpo castrense, determinaban el número de efectivos de cada unidad, así como los haberes que debían percibir en las distintas situaciones, ya fuesen estas el acuartelamiento, el traslado, la guerra viva, la enfermedad o la prisión castrense. Sin embargo, para conocer la situación de cada regimiento y, más aún, el estado específico de cada uno de sus miembros había que levantar reportes periódicos que lo determinasen. Algo que, se vislumbraba, se lograría con el pase mensual de revistas a cada regimiento. Con ello, se esperaba que cada militar recibiera el pago que le correspondiese, pero también que se evitase el desfalco del Real Erario en la medida en que no se pagaría a sus efectivos a partir de los meros componentes teóricos de cada regimiento (registrados en los pies de listas de los regimientos y batallones), sino del número y situaciones específicas que tuviesen en cada momento. Para realizar estas revistas, la ordenanza de 1705 estableció que en los ejércitos de Felipe V esta tarea fuese encargada a "Comisarios de Guerra, por cuya mano corran en adelante las muestras", es decir, reiteramos, las revistas de tropas. ${ }^{16}$

La figura de los comisarios de guerra estaba conectada de forma inextricable en cuanto al suministro de información con el principal organismo ideado por los ministros y asesores de Felipe $\mathrm{V}$ para el control del gasto militar que, lógicamente, era el gasto más copioso de su Erario Regio: la Tesorería Mayor de Guerra, precedente de lo que, años después, acabaría siendo la Tesorería General del Erario Regio de España. ${ }^{17}$ El tesorero mayor de Guerra debía gestionar el pago

13 Portugués, Joseph Antonio, Colección general, tomo X, 1765, pp. 327-328.

14 En la época "muestra" era sinónimo de "revista" y fue el término más general que se empleó en los siglos XVI y XVII.

15 Portugués, Joseph Antonio, Colección general, tomo X, 1765, p. 328.

16 Idem.

17 Entre los principales promotores de esta reforma militar y fiscal cabe señalar a Juan de Orry y a Joseph Grimaldo. Al respecto consultar: DuBEt, Anne, Un estadista francés, 2008. Para la evolución institucional de la Tesorería Mayor de Guerra a la Tesorería General, véase Torres SÁnchez, Rafael, La llave de todos los tesoros, 2012 y Dubet, Anne, y Solbes Ferri, Sergio, El rey, el ministro y el tesorero, 2019. 
de los montos específicos a que eran acreedores los diferentes regimientos; para ello se articuló una red de tesoreros en los diversos cuerpos del ejército de Felipe $\mathrm{V}$, que dependían jerárquicamente del tesorero mayor, los cuales estaban encargados del ajuste y pago mensual de los sueldos que debían percibir las tropas.

En la medida en que la situación específica de cada contingente de tropas dependía, como vimos, de una diversidad de situaciones, el procedimiento de pago se dividía en dos momentos: el adelanto por los tesoreros de una parte de los haberes a percibir en el mes, un procedimiento que se denominaba pagos a buenas cuentas, y el "ajuste" de cada soldado y oficial, que había que efectuar según los avatares que hubiesen ocurrido en ese lapso (combate, enfermedad, acuartelamiento, traslado, deserción, etc.). Sin embargo, para proceder al ajuste se precisaba de esa información que era la que debían suministrar los comisarios de guerra a los tesoreros de los ejércitos. La certidumbre de las muestras o revistas se depositaba en el hecho de que los reportes de los comisarios de guerra se hacían en presencia de los gobernadores, comandantes o sargentos mayores de las plazas donde se hallaban las tropas. Una presencia conjunta que, a modo de intervención, quedaba registrada con la firma conjunta del comisario y el militar al mando, y con la elaboración de copias debidamente firmadas, con lo cual ambas partes quedaban obligadas y adquirían responsabilidades ante el levantamiento de posibles cargos. Estas eran las garantías ideadas para que las muestras se levantasen "con legalidad". ${ }^{18}$ Iguales procedimientos se debían seguir con el estado de los equipajes de los trenes de artillería y las provisiones de víveres de los ejércitos.

Esta información debía canalizarse y ascender jerárquicamente: de las muestras de los regimientos había que entregar un extracto (un resumen sintético de las muestras) al sargento mayor de cada regimiento o, en su ausencia, al ayudante del regimiento, y otro extracto al comandante del ejército o gobernador de cada plaza. Asimismo, en el lapso de tres días se deberían hacer cuatro copias de estos extractos para que una de ellas llegase al Secretario de Estado y del Despacho Universal de Guerra (instrumento notorio de la irrupción de la vía reservada, al margen del orden polisinodial de los Consejos del reinado de los Habsburgo), ${ }^{19}$ otra al intendente de guerra, encargado de la subsistencia de las tropas en su distrito, otra al tesorero o persona establecida en cada plaza militar y una última al asentista o proveedor de pan y cebada de los regimientos, en el caso de que se tratase de los trenes de artillería o de los asentistas de víveres. ${ }^{20}$

Ahora bien, el sentido último de toda esta reforma estaba conectado con otro objetivo que se hacía patente en el colofón de la ordenanza de comisarios de guerra de 1705, cito:

17. Y siendo mi voluntad que todo lo establecido e impuesto en estas ordenanzas se observe, cumpla y ejecute inviolablemente, en la forma que se expresa, sin alteración, ni relajación alguna, ordeno y mando a todos mis Capitanes Generales,

\footnotetext{
18 Portugués, Joseph Antonio, Colección general, tomo X, 1765, p. 330.

19 Castro, Concepción de, A la sombra de Felipe V, 2004; Dubet, Anne, Un estadista francés, 2008.

20 Portugués, Joseph Antonio, Colección general, tomo X, 1765, p. 331.
} 
Comandantes, tenientes Generales, Gobernadores de Provincia, y de Plazas, Oficiales de Justicia, Policía y Hacienda, dentro de España, como asimismo a los Consejos de Guerra y Hacienda, y Contaduría Mayor de ella, por la parte que les toca, y puede tocar, que en todo se conformen, y arreglen a ellas, y las guarden, y hagan guardar, sin que en adelante intervengan en ellos los Oficiales de los Ejércitos y Plazas, ni cualesquiera otros que sea de este Ministerio, porque los extingo y revoco para siempre, que tal es mi voluntad $[\ldots] .{ }^{21}$

La extensa cita manifiesta la voluntad del monarca de separar a los militares del control del gasto de guerra, además de hacer desaparecer diversos oficios contables, como eran los veedores y contadores, que intervenían la actividad de los pagadores de los ejércitos con anterioridad a la creación de los comisarios de guerra. ${ }^{22}$

La formación de esta red de tesoreros y comisarios de guerra implicaba separar las esferas del Real Erario y la dirección castrense de los Ejércitos y los hechos bélicos. Una imbricación que había sido muy característica del reinado de los Habsburgo. El sostenimiento material de los ejércitos de Felipe V se asoció por tanto a un proyecto de recuperación del control por parte del monarca de su Real Erario. ${ }^{23}$

La evolución posterior de la figura de los comisarios de guerra del ejército en España no experimentó alteraciones de calado en las sucesivas normas que se fueron expidiendo entre 1705 y 1758. En este sentido las ordenanzas, reales órdenes e instrucciones que se elaboraron por Felipe V y Fernando VI ampliaron y aclararon aspectos que habían quedado sin resolver en la ordenanza de $1705 \mathrm{o}$ reformaron artículos específicos sobre los que se habían levantado pareceres contrapuestos. Cambios que tuvieron que ver también con las vicisitudes de la propia existencia de los intendentes de guerra y de provincia en España, en especial tras la implantación y desaparición de los de provincia entre 1718 y 1721 , y su reinstauración en 1749. Pero, reiteramos, no se modificaron los trazos generales de los comisarios de guerra. ${ }^{24}$ Tanto es así que, en el ya citado Diccionario de la lengua

21 Ibidem, p. 340. Las cursivas son nuestras.

22 Esteban Estríngana, Alicia, “Autopsia del despacho”, 2003; Dubet, Anne, Un estadista francés, 2008.

23 La gestión conjunta por parte de la alta oficialidad de la marcha de la guerra y el control del aprovisionamiento había generado fenómenos tanto de desabasto como de malversación de fondos. Separar ambas esferas pasó a ser un motivo recurrente de las actuaciones de la nueva dinastía. DuBET, Anne, Un estadista francés, 2008. Para el desarrollo de esta política en el siglo XVIII, consultar: Torres SÁnchEZ, Rafael, "La «militarisation» des finances", 2011.

24 Las principales normas elaboradas entre 1705 y 1758 se señalan en el apéndice I. Es de destacar que, en 1749, Raimundo Sanz, capitán de artillería, publicó en Barcelona una traducción de un Diccionario militar de términos del denominado "Arte de la Guerra" que se usaban o se habían usado en la monarquía francesa. En dicha obra, aparecen diversas modalidades de comisarios, a saber: comisario general, comisario ordenador, comisarios de víveres, comisario general de fortificaciones, además del comisario de guerra. Este último aparecía definido como: "es un oficial establecido para la política militar: en la marcha de las tropas, tiene cuidado de las dificultades que se tienen sobre la provisión de víveres y utensilios; pasa revistas a las tropas, queda con extracto, y da otro al general, uno al secretario de Estado de la guerra, al intendente y al tesorero". Es decir, mutatis mutandis, las características consignadas en las ordenanzas militares de España eran las del comisario de guerra en la monarquía francesa. SANZ, Raimundo, Diccionario militar, 1749, pp. 90-91. Cabe 
de la Real Academia Española, en su edición de 1780, tras aportar la voz general de "comisario", agregó una voz secundaria, "comisario de guerra", que fue definido como aquel "Ministro destinado para pasar revista a la tropa, y reconocer si están completos los regimientos y evitar los fraudes que suele haber." 25 Vemos pues la expresión aquilatada de lo establecido a principios del siglo XVIII: un cargo dotado de una facultad delegada, encargado de la revista de tropas, como instrumento de control del gasto de guerra. La cuestión que surge a continuación es ver cómo se produjo, y en qué contexto, la introducción de la figura de los comisarios de guerra en Nueva España.

\section{LOS AGENTES COMISIONADOS PARA DESEMPEÑARSE COMO CO- MISARIOS DE GUERRA EN NUEVA ESPAÑA (1727-1763): OFICIALES REALES Y CAPITANES DE PRESIDIOS}

Hasta la década de 1760, la presencia militar en el reino de Nueva España y sus provincias adyacentes de Nueva Galicia, Nueva Vizcaya, Yucatán y Tabasco, ${ }^{26}$ estaba muy acotada. Las principales unidades regulares se hallaban en los puertos de Veracruz y Acapulco, la Ciudad de México, la península de Yucatán y la red de presidios del septentrión. Una fuerza armada que, grosso modo, superaba apenas los 4,100 efectivos. $^{27}$

Los primeros conatos de reforma en materia militar en las Indias de Felipe V se produjeron en 1719 merced al reglamento que aprobó para el batallón y castillos de La Habana. Bajo este modelo, el virrey de Nueva España marqués de Casafuerte procedió a reformar en 1727 la normativa de su principal plaza militar: el presidio de Veracruz y el castillo de San Juan de Ulúa; para ello les expidió un Reglamento y ordenanzas.

Según el virrey, el mayor problema radicaba en que las tropas no estaban arregladas "en aquel orden y disciplina militar que pide el servicio y defensa de aquella plaza y castillo". ${ }^{28}$ Mediante la reforma se aspiraba al logro de dos objetivos básicos. Por una parte, fijar por reglamento el número de oficiales, soldados y artilleros de ambas guarniciones, así como los sueldos que debía gozar cada uno de los efectivos. Por la otra, "lo que se debe observar para su mejor gobierno, régimen, disciplina". Unos rubros que, entre otros aspectos, atañían al problema de las revistas de tropas dado que era a partir de ellas que se determinaba el pago específico de los sueldos mensuales de las unidades castrenses.

En este sentido, el apartado denominado "revistas y ejercicios" (concretamente, en el art. $5^{\circ}$ del reglamento) afirmaba:

señalar que la obra original, de Aubert de la Chenaye des Bois, publicada en París en 1743, era mucho más extensa (Chenaye des Bois, Aubert de la, Dictionnaire militaire, 1743). Sanz procedió a resumir lo que consideró era más adecuado para ilustrar sobre esta temática al público hispano.

25

26

27

28 
Todos los meses se ha de pasar revista de las compañías de dragones y artilleros de la guarnición de la Veracruz, ejecutándose esta del día ocho al quince del mes, por los Oficiales Reales de aquella Caja, en atención a no haber Comisarios de Guerra, con la asistencia del Gobernador. ${ }^{29}$

Siguiendo lo estipulado en el reglamento y ordenanzas para las guarniciones de Veracruz y San Juan de Ulúa, las revistas mensuales debían resumirse en extractos por parte de dichos oficiales reales, los cuales debían remitirse con la misma periodicidad al virrey. En ellas se tenía que hacer hincapié en las faltas de efectivos que se hallaren en cada compañía, dado que esto implicaba una reducción del monto total a erogar en el rubro de prest de tropa y sueldo de oficiales. Adicionalmente, el gobernador de Veracruz podía efectuar cuantas revistas de inspección considerase pertinentes a fin de reconocer la situación de los soldados de las compañías, su empleo efectivo en los cuerpos o, como era frecuente y se denunciaba, si se empleaban en otros fines, el estado de los uniformes y equipo de los caballos de los dragones. De todo ello se debería informar al virrey, en especial de lo que se considerase "digno de castigo". ${ }^{30}$

A partir del caso veracruzano, se puede apreciar que, a diferencia del ejército en España, las tropas novohispanas carecían de comisarios de guerra. $\mathrm{Su}$ escaso número y la dispersión de las fuerzas en un territorio enorme, en términos comparativos, derivó en que el cometido de las revistas se encargase a los "jueces oficiales reales" de las tesorerías regias, lo cual remite a las figuras de los contadores, tesoreros y, menos frecuente, factores con que estaban dotadas dichas dependencias de la Real Hacienda de Nueva España. Dada la distribución de tropas en el reino, esto significaba que la labor de comisarios de guerra se concentraba en los oficiales reales de las cajas de Acapulco, Mérida, Campeche, México y Veracruz.

La ausencia de comisarios de guerra y la encomienda de realizar el pase de revistas y formación de extractos a los oficiales reales del Erario de Nueva España se mantenía a mediados del siglo XVIII, tal y como se aprecia en el reglamento remitido por el marqués de la Ensenada en junio de 1749 para las tropas de Veracruz y San Juan de Ulúa, con motivo de la concentración de tropas navales en La Habana, tras la guerra de la Oreja de Jenkins. ${ }^{31}$ Los trazos generales de revistas, extractos y los de los encargados de ejecutarlos, previstos en 1727, se mantenían en el reglamento de 1749 , aunque con un desglose y precisión mayores. ${ }^{32}$ Así, por ejemplo, en el artículo 31 del nuevo reglamento se indicaba cuándo y quiénes debían realizar las revistas y los extractos y a quién se debían remitir:

29 Ibidem, f. 4. Las cursivas son nuestras.

30 Ibidem, f. 5.

31 Esto implicó el fin de la armada de Barlovento con sede en el puerto de Veracruz. OGELSBY, J. C. M., "Spain’s Havana", 1969.

32 Plan del reglamento que se idea para la guarnición de la Veracruz y castillo de San Juan de Ulúa, para sustituir el batallón de la Armada de Barlovento, que hacía el servicio en ambas plazas, cuando estaba desembarcado. AGN, Impresos oficiales, vol. 4, f. 6-11vta. 
Los oficiales reales de Veracruz, que ejercen en aquella plaza de Comisarios de Guerra, pasarán todos los meses a todas las referidas tropas revista, en la forma y para los fines que previenen las Reales Ordenanzas, y pasarán al virrey extractos de ellas, como se ejecuta el presente, celando en este particular todo lo que su Majestad les encarga en las mismas ordenanzas. ${ }^{33}$

Las consecuencias sobre los haberes de las tropas de Veracruz y San Juan de Ulúa eran inmediatas ya que los ajustes sobre el prest y sueldo derivaban de dichos documentos, como se consignaba en el artículo 34:

Cuando se libren pagamentos a dichas guarniciones, se ajustarán (como se hace ahora) por los extractos de las revistas de los meses, que se pagarán con rebaja de lo que por vía de préstamo hubieren recibido, y el importe de ellos se entregará, como el préstamo, a los ayudantes, para que lo distribuyan a los capitanes, y estos a sus soldados, con toda la justificación sin detenciones, y sin dar lugar a queja, digna de corrección, y el capitán de artilleros recibirá el de su compañía para la satisfacción de ella. ${ }^{34}$

Lo consecutivo y acumulativo de las normas, sin que esto plantease una ruptura a partir de los ordenamientos más actuales, se detecta en el artículo 66 del reglamento de junio de 1749 , en la medida en que se afirmaba que si algo de lo que ocurriese en el campo de "lo Económico y Gubernativo" no estuviese contemplado en la norma expedida por el marqués de la Ensenada, se seguiría lo previsto por el reglamento y ordenanzas del virrey Casafuerte en 1727, por su falta en lo determinado en el reglamento para la Habana en 1719, y faltando ambos, la normativa contemplada para España, según las reales ordenanzas "en cuanto fueren adaptables en este Reino".35

Si esta era la situación que se daba en las principales plazas militares de Nueva España, ¿qué sucedía en los presidios del Septentrión? Primeramente, cabe indicar que nos hallamos ante un espacio enorme que abarcaba una línea de más de 3,000 km de distancia, en el que la corona había ido instalando un archipiélago de presidios a remolque de la expansión demográfica y económica, con la minería de metales preciosos como principal motor de conquista y colonización. A partir de la visita que, por orden del virrey Casafuerte, efectuó el brigadier Pedro Rivera a dicho territorio durante casi cuatro años (entre 1724 y 1728), ${ }^{36}$ todo apunta a que no solo no había comisarios de guerra para la realización de las revistas y extractos, sino también a que estos instrumentos de control recaían en los propios oficiales de los presidios y no en los jueces oficiales reales de las tesorerías del Erario Regio. La razón básica era la enorme distancia que mediaba entre la sede de las cajas reales más septentrionales de la época (Durango, Zacatecas y San Luis Potosí) y unos presidios ubicados en las Californias, Sonora, Chihuahua, Nuevo México, Coahuila o Texas, por citar la ubicación de los

33 Ibidem, f. 10.

34 Idem.

35 Ibidem, f. 11 vta.

36 NaYlor, Thomas H. y Polzer, Charles W., Pedro Rivera, 1988. 
presidios más lejanos a dichas tesorerías. ${ }^{37}$ Que los encargados de realizar las revistas de tropas y sus extractos fuesen los mismos que estaban interesados en recibir el monto total del prest y sueldos de los presidios, los comandantes de estas unidades, implicaba una notable colisión de intereses, ya que eran ellos mismos los que debían proveerlos de alimentos, vestido, armas, etc. Productos que, se denunciaba, se ofrecían bajo un régimen de quasi monopolio a precios elevados y con calidades por debajo de lo esperado. Sin embargo, la precariedad de la estructura de control del Erario Regio en esta zona no permitía otra solución, so pena de gravar con mayores sueldos al Erario Regio con el nombramiento de comisarios ad hoc. ${ }^{38}$

\section{UNA CONSECUENCIA DE LA GUERRA DE LOS SIETE AÑOS EN NUEVA ESPAÑA: LA IRRUPCIÓN DE LOS COMISARIOS DE GUERRA FUERA DEL MARCO DE LAS INTENDENCIAS (1764-1785)}

El impacto de la derrota ante Gran Bretaña en la guerra de los Siete Años, en especial, las pérdidas de Manila y la Habana en 1762, obligaron a un reforzamiento del ejército continental en Nueva España, ya que con anterioridad la distribución de las tropas tenía una lógica de fronteras marítimas, frente a otras potencias europeas, y de consolidación del dominio territorial del Septentrión, contra una diversidad de pueblos indígenas conocidos bajo las denominaciones genéricas de apaches y comanches. ${ }^{39}$

En 1764, se inició el envío de contingentes de tropa veterana, en una expedición militar bajo las órdenes Juan Villalba como comandante general e inspector general del ejército. ${ }^{40} \mathrm{Al}$ mismo tiempo se fueron levantando milicias provinciales en el territorio. En 1766, los resultados en términos numéricos eran patentes. Las fuerzas de infantería sumaban 8,585 efectivos, de las que 1,842 eran tropas veteranas, 5,310 eran regimientos provinciales y 1,433 eran milicias urbanas, mientras que, en caballería, los efectivos sumaban 1,208 individuos, de los que 657 eran veteranos, 351 pertenecían a regimientos provinciales y 200 a milicias urbanas. Estos 9,793 soldados y oficiales, ${ }^{41}$ a los que había que añadir las tropas ubicadas en los presidios del norte (en 1742, tras la reforma de los presidios por parte del brigadier Pedro Rivera, sumaban 907 efectivos) y las tropas de

37 SÁNCHEZ SANTIRó, Ernest, Corte de caja, 2013, pp. 42 y 65-67.

38 El estudio de esta tensión y los posibles conflictos que generó son puntos por desarrollar en posteriores investigaciones.

39 SÁnCHEZ SANTIRó, Ernest, "El aprovisionamiento de las fuerzas", 2018.

40 En las ordenanzas del ejército de Carlos III de 1768 se indica que las funciones de los inspectores generales de infantería, caballería y dragones eran vigilar "que los cuerpos de su inspección sigan sin variación alguna todo lo previsto en mis ordenanzas para su instrucción, disciplina, servicio, revista, manejo de caudales y su gobierno interior". El desglose de estas funciones se realiza en 33 artículos del título VIII del tratado $3^{\circ}$ de las ordenanzas carolinas. Ordenanzas del Ejército, 1841, pp. 149-155. Archer, Christon I., The Army in Bourbon Mexico, 1977; GóMEz PÉREz, Carmen, El sistema defensivo, 1992.

41 "Estado general de las tropas de este Reino [1766]". AGN, Indiferente de guerra, vol. 151. Hay que señalar que las fuerzas de las milicias urbanas no eran financiadas con cargo a la Real Hacienda ni formaban constitutiva del ejercito virreinal, como sí lo eran las tropas veteranas (o de línea) y las milicias provinciales. 
Yucatán (aproximadamente, unos 590), ${ }^{42}$ representaba una fuerza armada de 11,290 hombres. Si, como dijimos, el ejército en Nueva España apenas superaba los 4,100 individuos a finales de la década de 1740, el salto que representó la política de Carlos III por reforzar la defensa interna de Nueva España es notorio; de hecho, se incrementó en 7,190 efectivos.

En este contexto, tuvo lugar la aparición en suelo novohispano de comisarios de guerra de dicha tropa veterana, encargados de realizar las revistas y extractos. Uno de los primeros ejemplos de esta figura lo encontramos en la persona de José Nicolás de Ulibarri, vecino de Puebla y antiguo proveedor de presidios que venía actuando en la región, al menos, desde la década de $1750 .{ }^{43}$ A partir de 1765 , se desempeñó como "comisario de guerra de tropas veteranas de Puebla, provincia de Tlaxcala, Tepeaca, villa de Córdoba y Atlixco", además de ejercer como "comisario de víveres" (es decir, proveedor) del ejército, quien desempeñó estos cometidos entre 1765 y 1770, cuando falleció. En ese momento, el cargo pasó a José Ramos Figueroa, quien se desempeñó como comisario y tesorero de guerra, también en la ciudad de Puebla. ${ }^{44}$ Apenas estuvo unos meses en dichos cometidos, dado que por enfermedad fue substituido a finales de $1770^{45}$ por Francisco José de Larrasquito, antiguo regidor del cabildo de Puebla y hacendado ganadero. ${ }^{46}$

Larrasquito, además de recibir las listas de filiación de la tropa (listas nominales de los componentes de cada unidad) ${ }^{47}$ y de confeccionar revistas y extractos ${ }^{48}$ o de proveer víveres, se encargó también de asegurar la financiación para la revisión y compostura del armamento y de la ubicación de inmuebles aptos para el acuartelamiento de tropas en la ciudad de Puebla. ${ }^{49}$ Esta acumulación de cometidos en el ramo de guerra le acercaban claramente a las funciones que ejercía un intendente en la causa homónima. ${ }^{50}$

Lamentablemente, no contamos con un estudio detallado sobre estos personajes, ${ }^{51}$ ni de sus relaciones con otros "comisarios de ejército y Real Hacienda" 52 que aparecen citados en alguna documentación de la época, lo cual arrojaría luz más extensa sobre los cambios experimentados en el control del gasto de guerra acaecidos con la llegada de tropas veteranas a Nueva España. Sin

42 Sánchez SAntiró, Ernest, Corte de caja, 2013, pp. 42 y 44.

43 En dicha década, Ulibarri recibía recursos de manos de los administradores de la renta de alcabalas del distrito de la aduana de Puebla y con ellos adquiría los víveres y enseres que los oficiales reales de la caja de Veracruz debían remitir a los presidios ultramarinos como parte del gasto estipulado como "situados". En este concepto era un "comisario" o "proveedor" de víveres, y con ambas denominaciones aparece mencionado en la documentación. AGN, General de Parte, vol. 38, Exps.113, 130, 169; vol. 41, Exps.80, 190, 248. AGN, Alcaldes Mayores, vol. 2, fs. 55-57vta.

45 AGN, Alcaldes Mayores, vol. 2, fs. 116-116vta, fs. 243-243vta.

46 AGN, Indiferente virreinal, caja 549, Exp. 41.

47 AGN, Indiferente virreinal, caja 1698, Exp. 3.

48 AGN, Indiferente virreinal, caja 5249, Exp. 28.

49 AGN, Alcaldes Mayores, vol. 2, f. 348, fs. 385-387, fs. 436.

50 AGN, Indiferente virreinal, caja 202, Exp. 17; caja 4031, Exp. 9.

51 La principal obra sobre el ejército de Nueva España en el periodo 1760-1810 (ARCHER, Christon I., The Army in Bourbon Mexico, 1977) no hace mención a dicha comisaría de guerra, ni a esos personajes.

52 AGN, Indiferente virreinal, caja 6363, Exp. 97. 
embargo, y a pesar de la carencia, se puede afirmar que la arribada de estos contingentes llevó a que se crease una tesorería de ejército especializada en el gasto de guerra. Los nuevos cuerpos armados procedían de un espacio donde la existencia de comisarios de guerra era algo habitual para la determinación del pago de sus haberes. Parecía lógico, pues, que su arribo fuese acompañado de la erección de este tipo de comisionado.

Desde esta instancia se ejerció el control contable sobre la tropa veterana desplegada precisamente en una región que se consideraba estratégica, ante el posible ataque de tropas británicas que, se preveía, tendría lugar por el puerto de Veracruz. Un área que abarcaba grosso modo las localidades de Puebla, Tlaxcala, Atlixco y las villas de Córdoba, Jalapa y Orizaba. Se pretendía crear una barrera militar que impidiese el acceso del enemigo al interior del virreinato.

Este tesorero de ejército fue encargado también para desempeñarse como comisario de guerra, acumulando así varias responsabilidades. Lo relevante es que para ejercer estas actividades debía estar en continúa comunicación con el virrey, en tanto capitán general del Ejército de Nueva España, con los oficiales reales de la caja de México, encargados, en principio y como ya señalamos, de desempeñar las funciones de comisarios de guerra, con los administradores de alcabalas de la ciudad de Puebla, fuente cercada de recursos para sufragar dichos gastos, así como con otros administradores de rentas de la corona en la región poblana (v.g. novenos reales, vacantes mayores y menores, bula de santa cruzada, etc.) y con los oficiales reales de la caja de Veracruz, encargados estos últimos de financiar y proveer, como ya dijimos, los situados en especie y dinero para el Gran Caribe. Un puerto que, además, era la puerta de entrada de tropas veteranas procedentes de España.

Cabe suponer que el tesorero de ejército y comisario de guerra ubicado en Puebla ejerció sus responsabilidades gracias a la subdelegación de funciones que estaban encargadas a los oficiales de las cajas reales. De hecho, hemos podido rastrear correspondencia entre ambas instancias, bajo parámetros de dependencia del comisario de guerra de Puebla ante los jueces oficiales reales de la caja matriz de México. ${ }^{53}$ Sin embargo, esto es algo que hay que verificar en trabajos ulteriores, así como el hecho de su perduración, pues hemos podido apreciar que el rastro de dicho tesorero de ejército y comisario de guerra se pierde en la década de 1780 .

La existencia de estos comisarios de guerra, ubicados en Puebla, no implicaba que los oficiales reales dejasen de estar comisionados para ejercer la comisaría de guerra de aquellas tropas que les estuviesen encargadas, en tanto gestores del gasto de guerra. Así ocurrió, por ejemplo, con las tropas ubicadas en la Ciudad de México. Por otra parte, en el caso de los presidios de la frontera interior de Nueva España se mantuvo la práctica de revistas de la tropa por parte de los capitanes o gobernadores de los presidios, tal y como se aprecia en el Reglamento e instrucción de presidios que elaboró el marqués de Rubí, en el contexto de la visita general que entonces estaba realizando José de Gálvez en Nueva

$\overline{53}$ AGN, Indiferente virreinal, caja 4031, Exp. 9. 
España, el cual fue aprobado por la corona según una real cédula de 10 de septiembre de $1772 . .^{54}$

En el título noveno de dicho reglamento e instrucción, dedicado a las "revistas mensuales" se indicaba:

El capitán pasará mensualmente revista a su compañía, y formará un extracto con expresión de los nombres de los oficiales, sargentos, cabos, soldados y capellán; a los que se hallasen presentes pondrá al margen una P; a los empleados el destino; y los empleos o plazas vacantes se indicarán con una $\mathrm{V}^{55}$

Es decir, el comandante militar del presidio seguía siendo la autoridad comisionada para la realización de las revistas y extractos. De estos últimos se debían sacar dos copias con destino a un "comandante inspector de presidios internos" 56 quien, como cargo paralelo del inspector general del ejército, creado en Nueva España 1764, ${ }^{57}$ debía mandarlos tras su supervisión al virrey, siendo esta tarea una parte de los avisos y noticias que estaba obligado a remitir sobre el estado y fuerza de los presidios, así como todo lo relativo a las entradas y operaciones de guerra que se proyectasen o ejecutasen. Asimismo, estaba encargado de la "instrucción, disciplina, servicio, manejo de caudales, interior gobierno, provisión" de la línea de presidios internos. Un cometido que debía realizar de manera periódica ya que los presidios debían ser visitados anualmente, ya fuera directamente por el comandante inspector o por los dos ayudantes que se le destinaban a tal efecto en el reglamento de 1772.58

A la luz de estas evidencias, parece claro que la mayor presencia de tropas en Nueva España a partir de 1764 obligó a que las dos instancias encargadas de la realización de las revistas y extractos de tropas hasta entonces, a saber, los oficiales reales de las cajas del Erario de Nueva España y los comandantes de los presidios internos, conviviesen con comisarios de guerra, que irrumpían en el escenario institucional. Asimismo, se aprecia a partir de entonces el surgimiento de instancias intermedias entre estos comisionados y el virrey, en tanto capitán general de ejército de Nueva España y superintendente general de Real Hacienda: los inspectores/subinspectores generales del ejército y de los presidios internos. Las relaciones entre estos actores ameritan también un estudio pormenorizado, pues con la historiografía disponible desconocemos la interacción que hubo entre estas instancias de control, así como los posibles conflictos o traslapes de funciones que pudieron originarse. ${ }^{59}$

En 1776, este cargo lo detentaba José Rubio que, al efecto, fue ascendido al grado de coronel de infantería del ejército. AGI, Guadalajara, leg. 515, núm. 103.

57 Entre 1764 y 1766, el cargo de inspector general lo ejerció el comandante general del ejército de Nueva España, Juan Villalba. Para sus sucesores, nombrados como subinspectores generales, entre 1767 y 1789 , consultar: http://www.historicas.unam.mx/publicaciones/publicadigital/libros/realestampilla/007_01.html [consulta: 26 de octubre de 2020]. Archer, Christon I., The Army in Bourbon Mexico, 1977.

58

Reglamento e instrucción, 1772, f. 12.

9 En ciertas obras se puede apreciar la actuación de estos inspectores y subinspectores de guerra en Nueva España, pero son trabajos que no atienden al problema del pase de revista y los comisarios de guerra. Al respecto consultar: LoSA CONTRERAS, Carmen, "La formación de la milicia", 2006. 


\section{LA ORDENANZA DE INTENDENTES DE NUEVA ESPAÑA Y LA CAUSA DE GUERRA (1786-1816): LOS COMISARIOS DE GUERRA, LOS ACANTO- NAMIENTOS MILITARES Y LA GUERRA CIVIL NOVOHISPANA}

La ordenanza de intendentes para Nueva España de diciembre de 1786 no modificó los cometidos básicos de los contadores y tesoreros de las cajas reales en su desempeño como comisarios de guerra. Si en algo destaca es por la estructuración de funciones y la descripción prolija de los encargados, las dependencias y los procedimientos implicados en el pase de revista y realización de extractos, todo ello en el marco de la denominada "causa de guerra" que deberían desempeñar los intendentes de ejército y provincia de Nueva España. En este sentido, los intendentes debían atender en la causa de guerra a la subsistencia, economía y policía en general de las tropas, toda vez que el cuidado particular de los cuerpos armados recaía en los inspectores de guerra, de presidios y de sus jefes directos. Bajo esta premisa, el principal cometido del intendente era proporcionar los recursos para los haberes del ejército y la provisión de víveres, en los casos en que los propios cuerpos armados no se encargasen de este último cometido. ${ }^{60} \mathrm{Un}$ encargo que, cuando se producía, era ejercido mediante la figura de los habilitados castrenses. ${ }^{61}$

Como señalaba la ordenanza, las revistas eran "el principal instrumento que legitima los pagos y subministraciones que se hagan a las tropas, oficiales y demás individuos pertenecientes a Guerra", por ello lo intendentes debían cuidar de su exactitud y formalidad, asegurándose que se pasasen "por filiación", asentando con claridad los presentes y los ausentes a fin de que no se viesen perjudicados los cuerpos armados, ni la Real Hacienda. ${ }^{62}$ Para realizarlas se establecían plazos precisos (entre el 5 y el 15 de cada mes), siendo los encargados de efectuarlas los ministros de Real Hacienda contadores y tesoreros, ya fuesen generales, principales o foráneos, ${ }^{63}$ "pues unos y otros han de hacer en aquel Reino, y en sus respectivos distritos, las funciones de Comisarios de Guerra". ${ }^{64}$ En aquellos parajes en que hubiesen tropas del ejército virreinal (veteranas, provinciales o presidiales) lejanas de las capitales provinciales (asimiladas las provincias a las

60 Art. 251. Real ordenanza, 1984, pp. 348-349.

61 En Nueva España, el habilitado era un oficial subalterno (teniente o alférez) nombrado por elección en cada compañía. Sus encargos eran varios, destacando el cuidado del pago de la tropa, la provisión de raciones, vestuario, monturas, etc. Una actividad que era realizada bajo la supervisión de los capitanes de las compañías. SÁNCHEZ SANTIRó, Ernest, "El aprovisionamiento de las fuerzas", 2018, p. 363.

62 Art. 283. Real ordenanza, 1984, pp. 380-381.

63 Con la ordenanza de intendentes de 1786 los antiguos jueces oficiales reales se transformaron en "ministros de Real Hacienda contadores y tesoreros". No se trataba de un mero cambio de denominación, ya que era la evidencia de un cambio fundamental: contadores y tesoreros perdieron la jurisdicción en materia de Hacienda, misma que se concentró en los intendentes. De igual manera, la ordenanza de 1786 reglamentó la jerarquía que existía de facto entre las tesorerías del Erario Regio novohispano al determinar que habría una Tesorería General de Ejército y Real Hacienda en la Ciudad de México, como capital del reino, tesorerías Principales en las capitales del resto de intendencias, y tesorerías foráneas, que eran antiguas cajas reales que con la nueva organización provincial habían quedado inscritas en algunas de las intendencia que ahora se creaban, siempre que no fuesen la tesorería de la capital provincial. JÁuREGUI, Luis, La Real Hacienda, 1999. 
intendencias), los intendentes nombrarían "comisarios substitutos", teniendo aquí preferencia los dependientes de la Real Hacienda. Un nombramiento que debía recibir la aprobación del Intendente general de Ejército del Reino. ${ }^{65}$

Aunque no era explícito, las únicas rentas que tenían una presencia ubicua en el territorio novohispano eran las que gestionaban las aduanas internas (en especial, las alcabalas y la renta de pulques) y el estanco del tabaco. ${ }^{66}$ Sus empleados estaban llamados a desempeñar el cometido de comisarios de guerra sustitutos, en parajes alejados de las tesorerías general, principales y foráneas. Dada la distribución del ejército en Nueva España esta realidad remitía al amplio Septentrión y a las tropas que no estuviesen bajo el régimen de los presidios internos.

La ordenanza de intendentes generalizó también un mecanismo de control sobre la veracidad de las revistas al establecer la intervención del cabo militar que debía estar presente en cada revista mensual. Las revistas debían ir firmadas no solo por los que se desempeñaban como comisarios de guerra sino por estos suboficiales. Solo bajo estos supuestos los intendentes y los contadores de ejército de México y los de las tesorerías principales admitirían las revistas y los extractos que de ellas debían emanar. ${ }^{67}$

El fin último de todo este procedimiento remitía al pago de los alcances del sueldo de los oficiales y el prest de los soldados que no hubiesen sido cubiertos por los pagos iniciales "a buenas cuentas", así como de "toda clase de gratificaciones" que debiesen recibir los cuerpos armados. Sobre los extractos de revistas elaborados por los comisionados para fungir de comisarios de guerra titulares o substitutos, las contadurías principales de las diversas intendencias debían efectuar los ajustes en los haberes de las tropas, mismos que debían ser "visados" por los intendentes para dar su visto bueno. ${ }^{68}$ Con este trámite, más el recibo de los extractos por los habilitados de las compañías y la notificación de estos en los cuadernos que debían llevar dichos habilitados por parte de los ministros de Real Hacienda ${ }^{69}$ se procedía al pago de los ajustes de las tropas, dado que una parte de los haberes se habían recibido previamente con cargo a buenas cuentas. ${ }^{70}$

65 Idem.

66 Para la distribución en el Reino de las aduanas y receptorías de alcabalas y pulques a la altura de 1810, como resultado de un proceso que generalizó desde 1776 el régimen de aduanas y la administración por parte de empleados de la corona, consultar: SÁnchez SAnTIRó, Ernest, "La Hacienda reformada", 2001 y La imperiosa necesidad, 2016, p. 319.

67 Incluso se determinó cómo certificar la intervención. El cabo debía indicar, "Intervine en esta revista Yo el infrascripto (aquí su nombre y apellidos), y está ejecutado este Extracto según el número de oficiales, Sargentos y Soldados que han estado presentes y efectivos, sin que se hayan restituido ni asistido a ella los que se declaran destinados y empleados [...]”. Art. 283. Real ordenanza, 1984, pp. 352-353. La cursiva en el original. Este procedimiento es reproducción casi literal de lo previsto en la ordenanza de intendentes de España de 1718. Un procedimiento que generó malestar, por el incremento de tareas que representaba para los contadores principales de las provincias. Al respecto, consultar: DUBET, Anne, La Hacienda real, 2015.

69 Aquí se seguía lo previsto en la Ordenanza General del Ejército de Carlos III aprobada en 1768, concretamente el artículo $9^{\circ}$ del título $9^{\circ}$ del Tratado $1^{\circ}$ que indicaba: "Siempre que el habilitado perciba caudales de la tesorería, bien sea por ajuste final, o buenas cuentas, deberá notar el tesorero en un cuaderno que el habilitado ha de tener para su registro, la cantidad que libra; y en qué especie, rubricando esta noticia; y nunca será el cuerpo responsable, sino de lo que en el libro se halle rubricado". Ordenanzas del Ejército, 1841, p. 25. 
Como en anteriores procedimientos toda esta documentación debía elevarse a diferentes oficinas y autoridades. Así, contadores, tesoreros y comisarios substitutos debían elaborar cuatro copias de los extractos visados por el intendente, los cuales debían ir acompañados de los documentos que justificasen las diversas situaciones de los miembros de los cuerpos armados (enfermedad, traslado, comisión, deserción, etc.) para que fuesen depositados en el archivo de la Contaduría Principal de la provincia. De ellas, una se mandaría a la Secretaría de la Intendencia y las otras tres al intendente general de Ejército, quien, a su vez, guardaría una copia en su archivo y las otras dos se mandarían a la Contaduría General de Ejército y Real Hacienda de Nueva España y al secretario de Estado y del Despacho de Indias. ${ }^{71}$ De este modo se alcanzaba la cúspide del gobierno del Erario Regio prevista en la ordenanza de intendentes de 1786, en la medida en que dicho secretario también detentaba la Superintendencia General de Real Hacienda de Indias, cargos ejercidos entonces por José de Gálvez.

En febrero de 1788, el virrey Manuel Antonio Flores solicitó a Eusebio Ventura Beleña, oidor de la Audiencia de México, un parecer general sobre la ordenanza de intendentes de 1786, que apenas puesta en práctica ya había experimentado cambios, en especial, tras la muerte de José de Gálvez en $1787 .{ }^{72} \mathrm{El}$ informe se elaboró con celeridad de manera que, a finales del mismo mes, estaba concluido y elevado al virrey. En él encontramos una opinión sobre el desempeño de los ministros de Real Hacienda como comisarios de guerra. En este sentido, al tratar sobre aspectos generales de la causa de guerra, Ventura Beleña indicó:

[ítem,] 13. En esta Nueva [España] no hay decadencia respecto del ramo económico de Guerra porque desde el año de 1764 no vino Tropa Veterana, y desde entonces se ha celado la inversión de caudales por los respectivos Oficiales Reales en calidad de Comisarios de Guerra con bastante escrupulosidad y esmero, sin desfalco alguno considerable. ${ }^{73}$

Si bien sabemos que los oficiales reales ejercían desde mucho antes de 1764 la función de comisarios de guerra, lo que deseamos destacar aquí es la favorable opinión de actores ubicados en los órganos centrales de gobierno del Reino, caso de la Real Audiencia de México, en torno a su desempeño en la comisión encargada para el control del gasto de guerra. Por otra parte, ni la ordenanza de intendentes de 1786, ni el parecer del oidor de la Real Audiencia hacen ya referencia al tesorero de ejército y comisario de guerra creados en 1765 .

La evolución de la política internacional de la corona llevaría a que la figura de los comisarios de guerra volviese a hacer acto de presencia en el Erario Regio de Nueva España, aunque bajo otra modalidad: los comisarios de guerra acotados temporalmente en su ejercicio a acciones bélicas. Entre 1796 y 1808, la Monarquía hispánica enfrentó dos guerras contra Gran Bretaña, separadas por un breve cese de hostilidades (1802-1804), con motivo de la Paz de Amiens. Si bien

\footnotetext{
71 Art. 284. Real ordenanza, 1984, pp. 383-385.

72 Pietschmann, Horst, Las reformas borbónicas, 1986; JÁuregui, Luis, La Real Hacienda, 1999.

73 "Introducción", Real ordenanza, 1984, p. XXXIII.
} 
la mayoría de las acciones bélicas adquirieron la forma de guerras navales, en algunos casos también hubo episodios de conquista territorial como el intento británico de asentarse en la ciudad y puerto de Buenos Aires (1806), desembarco que, no sin dificultad, logró ser repelido por las fuerzas armadas virreinales rioplatenses. En este sentido, el peligro de una invasión británica a Nueva España volvía a ser una amenaza viva a la que las autoridades del virreinato tuvieron que dar respuesta.

Se preveía, una vez más, que la invasión tendría lugar por el puerto de Veracruz, ante lo cual el virrey Branciforte, junto a los generales del ejército novohispano, consideró que había que adiestrar al cuerpo armado en el propio escenario donde se preveía que se iba a desarrollar el enfrentamiento. La estrategia diseñada pasaba por el acantonamiento de un grueso contingente de tropas en la zona denominada como "las Tres Villas" (subdelegaciones de Orizaba, Córdoba y Xalapa), próxima, como ya vimos, al puerto de Veracruz, pero sin los problemas derivados de las enfermedades endémicas que azotaban a la costa, en especial la fiebre amarilla y la disentería.

El primer gran acantonamiento se produjo en la subdelegación de Orizaba en 1797, e implicó la movilización de casi 7,000 efectivos del ejército novohispano. Para enfrentar los retos que implicaba la gestión económica del acantonamiento (pago de haberes, habitación, alimentación y vestido de la tropa, reparación del armamento, alimento y establos de caballos y mulas, almacenaje de insumos y pertrechos de guerra, levantamiento de hospitales de campaña, etc.), el virrey Branciforte nombró a José Rendón, que se desempañaba entonces como intendente de provincia de Zacatecas, como intendente general provisional del ejército acantonado. ${ }^{74} \mathrm{La}$ "provisionalidad" derivaba del hecho de que era el virrey quien detentaba la titularidad del cargo de intendente de guerra en Nueva España, tras la reforma de la ordenanza de intendentes en 1787.

Para que el intendente Rendón pudiese llevar a cabo su comisión tuvo que dotarse de una mínima estructura administrativa compuesta por un secretario, un tesorero, así como diversos contadores, oficiales y escribientes habituados al manejo de cuentas. Sin embargo, de esta estructura burocrática nos interesa destacar el problema del pase de revistas y la elaboración de extractos con los que se debía efectuar el pago de los haberes del ejército acantonado. Haciendo uso de las facultades que como intendente de ejército le había delegado el virrey Branciforte, Rendón nombró tres comisarios de guerra para que realizasen las revistas y extractos de las tropas ubicadas en las diversas localidades de la subdelegación de Orizaba. ${ }^{75}$ Con ello volvió a hacer acto de presencia esta figura en el cuadro institucional del Erario Regio de Nueva España, aunque ahora bajo la supervisión y al servicio del intendente de ejército. Al respecto cabe preguntarse por los motivos de esta reaparición.

Hasta 1796, las diversas unidades del ejército de Nueva España, con excepción de las tropas presidiales, se hallaban ubicadas mayoritariamente en impor-

74 Archer, Christon I., The Army in Bourbon Mexico, 1977, pp. 122-123.

75 Ibidem, p. 123. 
tantes núcleos urbanos, tanto del interior como de las costas (México, Veracruz, Acapulco, Campeche, Puebla, Guadalajara, San Luis Potosí, Durango, Oaxaca, Querétaro, Isla del Carmen, etc.). ${ }^{76}$ Por otra parte, como indicó Ventura Beleña, desde 1764 no habían arribado nuevos contingentes de tropa veterana a Nueva España que, recordamos, habían ido acompañados del nombramiento de un tesorero de ejército y comisario de guerra, con sede en la ciudad de Puebla. A la altura de la década de 1780, y más aún con la ordenanza de intendentes de 1786, todas las localidades citadas previamente contaban o bien con tesorerías principales o bien con tesorerías foráneas, de manera que disponían de ministros contadores y tesoreros para desempeñar el cargo de comisarios de guerra. Es decir, la red de tesorerías regias se había fortalecido. Sin embargo, el acantonamiento, agrupando un número como nunca antes en Nueva España de tropas veteranas y milicianas en un espacio relativamente reducido, carente además de tesorerías principales o dependientes, unido a la necesidad de contar con un mando centralizado de las cuestiones económicas de la guerra, sin que se dejasen descubiertas las obligaciones militares y hacendarias del puerto de Veracruz, llevó a que Rendón instaurase la figura de comisarios de guerra, siguiendo la estructura que, como vimos previamente, era común en el ejército en España desde principios del siglo XVIII. ${ }^{77}$ A partir de este momento, cada vez que se produjese un acantonamiento o se levantase un ejército, como ocurrió tras el estallido de la guerra civil novohispana en 1810, la figura de los comisarios de guerra estaría unida a dichos contingentes armados, ya fuesen los previstos en la ordenanza de intendentes de 1786 o los nombrados exprofeso para tal cometido. El cúmulo de tareas de los ministros contadores y tesoreros de las cajas reales, la lejanía de las tropas de estos puntos o la propia movilidad de los efectivos armados, en el caso de guerra, interna motivaron, según los momentos, que dichos ministros no ejerciesen la comisión de comisarios de guerra. El caso extremo se produjo tras el estallido de la insurgencia en 1810.

Al constituirse el Ejército del Centro en octubre de 1810, comandado por el brigadier Félix María Calleja, en respuesta al levantamiento insurgente, se procedió al nombramiento de un comisario de guerra, con sede en Querétaro, el cual levantó las primeras listas y extractos de tropas de dicho cuerpo armado. ${ }^{78}$ Asimismo, por diversos reportes, sabemos de la actividad de los comisarios de guerra asociados a otros contingentes armados contrainsurgentes (los ejércitos del sur, del norte, de reserva, o diversas divisiones de tropas) ${ }^{79}$ y de varias iniciativas para

\footnotetext{
$\overline{76}$ Ortiz EsCAmilla, Juan, Guerra y gobierno, 2014, pp. 95-101.

77 La referencia al marco institucional es relevante dado que entre los miembros del ejército de Nueva España e, incluso, entre los ministros y oficiales de la Real Hacienda podía haber individuos que detentaran el título de comisarios de guerra, ya porque lo hubiesen adquirido en España, ya porque habían accedido al mismo bajo la modalidad de comisarios de guerra "honorarios", pero eso no significaba que estuviesen ejerciendo una comisión para la realización de revistas y extractos de tropas con miras al pago de sus haberes. Para ejemplos de solicitudes de dicho nombramiento honorario en Nueva España, véase AGI, Correos, legs. 150C y $236 \mathrm{~B}$.

78 AGN, Indiferente virreinal, caja 1298, Exp. 10.

79 Serrano Ortega, José Antonio, Jerarquía territorial, 2001, pp. 106-107.
} 
la constitución y regulación del funcionamiento de las comisarías de guerra en el bienio 1812-1814. ${ }^{80}$ Sin embargo, tampoco disponemos de estudios sistemáticos sobre esta figura en el crítico periodo de 1810-1816, etapa en la que se produjeron los hechos más cruentos de la guerra civil novohispana. Lo que sí parece evidente es que, con el cambio de coyuntura bélica a partir de 1816, cuando los principales contingentes de las tropas insurgentes habían sido derrotados o integrados al orden virreinal, en el marco de una amplia política de indultos, ${ }^{81}$ el panorama de la Hacienda virreinal y, por tanto, de control sobre el gasto militar era cuanto menos fragmentario. El control político y militar del territorio del Reino de Nueva España por parte del gobierno virreinal se había debilitado y eso había tenido su reflejo en el funcionamiento de la Real Hacienda. ${ }^{82}$ El cambio de coyuntura bélica y la llegada de un nuevo virrey a Nueva España, Juan Ruiz de Apocada, dieron paso a una transformación institucional del ejército de Nueva España que impactó en el funcionamiento de los comisarios de guerra, lo que llevaría a la creación de la Comisaría General de Guerra en 1817, una instancia de control que apenas ha empezado a ser estudiada y que amerita una atención mayor. ${ }^{83}$

\section{CONCLUSIONES}

Guerra y Hacienda constituyen un binomio tradicional en los estudios sobre la formación de las capacidades burocráticas y de gobierno de los erarios regios en la Época Moderna. En este sentido, el estudio sobre el perfil y desarrollo de los comisarios de guerra en Nueva España refuerza la necesidad de mantener en continua comunicación los estudios de ambas esferas, sabiendo que los procesos acaecidos en los diversos territorios y periodos no son transferibles de manera mecánica y simple. De hecho, el rastreo de la figura de los comisarios de guerra del ejército borbónico en dos espacios, España y Nueva España, permite constatar cómo una misma función, levantar revistas y extractos de tropas para determinar los ajustes que sustentasen el pago de los haberes de la tropa y la oficialidad de los ejércitos, podía adquirir formas institucionales disímiles y no por ello menos operativas. Resalta, por tanto, la capacidad de adaptación de las autoridades de los erarios regios a las diversas condiciones de los territorios: el volumen total del contingente armado, su dispersión en el territorio, la distribución de las tesorerías regias, la disponibilidad de agentes capacitados, en conjunción de una constante voluntad de aminorar y controlar en todo lo posible el gasto de guerra de los erarios y del peso de los agentes inmiscuidos en el pago de los haberes de la tropa, unos montos que podían representar una fuente de liquidez con cargo a la Real Hacienda. Todos ellos son factores para conjugar en el análisis.

Un trazo que distingue a la figura del comisario de guerra en Nueva España es su relativa aparición tardía, dado que sus funciones fueron desempeñadas por

\footnotetext{
80 AGN, Indiferente de guerra, vol. 142.

81 Ortiz EsCAmilla, Juan, Guerra y gobierno, 2014.

82 JÁuREGUI, Luis, "La problemática administrativo-fiscal...", 2020, p. 39.

83 SÁNCHEZ SANTIRó, Ernest, La imperiosa necesidad, 2016.
} 
otros actores, ya fuesen los oficiales reales de las tesorerías regias o, incluso, los propios comandantes de armas, caso de los presidios internos. Esto último contravenía a los propios intereses de la corona en cuanto al control del gasto de guerra, al ser una parte interesada en que no se disminuyese el monto asignado a cada guarnición presidial. La arribada de tropa veterana en 1764 a Nueva España alteró el panorama institucional, al crearse una tesorería de ejército ejerciendo además la comisaría de guerra de dicha tropa. Una tesorería y cometidos que, consideramos, necesitan un estudio más detallado. Su vigencia parece ser que solo perduró hasta la década de 1770, ya que en el momento en que se introdujo la ordenanza de intendentes de 1786 no estaba contemplada en la organización de la Hacienda virreinal.

En el marco del nuevo régimen de intendencias, la red de tesorerías regias, con su correlato de ministros oficiales y contadores, cada vez más potente y capilar, encargados de ejercer la comisaría de guerra en sus distritos, vino a ocupar su lugar. Sin embargo, el incremento de las acciones de guerra a partir de la década de 1790, en espacios alejados a dicha red, motivó que se delegase la función de comisarios de guerra en una diversidad de cargos (oficiales de presidios, ministros de tesorerías, empleados de administraciones de rentas, etc.). La movilización de los recursos humanos de guerra en Nueva España, como nunca antes, en el contexto de las guerras finiseculares contra Gran Bretaña, llevaron a que se tuviese que superar el ordenamiento institucional derivado de la ordenanza de intendentes de 1786. La guerra civil novohispana no varió el rumbo, solo incrementó la presencia e incidencia de los comisarios de guerra, en el contexto de una expansión sin precedentes de las tesorerías militares, para las cuales todavía no contamos con estudios específicos que muestren su funcionamiento. En este contexto, consideramos que la Comisaría General de Guerra, creada en 1817, representó la voluntad de las autoridades virreinales por reconstruir un control centralizado sobre el gasto de guerra. ${ }^{84}$

Tras este recorrido se puede concluir que la figura de los comisarios de guerra en Nueva España tuvo un origen diverso: la ampliación de funciones otorgada a los oficiales de las cajas reales y administradores de rentas y los nombramientos ad hoc realizados por los intendentes o los efectuados por comandantes militares con motivo de episodios bélicos. Una misma denominación que, sin embargo, oculta alcances disímiles en sus facultades y permanencia en el encargo, mismo que dependió de su origen institucional y las circunstancias en que tuvieron que ejercer sus comisiones.

Sería interesante rastrear en qué medida esta configuración marcaría a una de las figuras hacendarias más relevantes de México durante su primera República federal (1824-1835): los comisarios de la Federación. ${ }^{85}$ Un aspecto que debe conectarse con el peso político y económico que adquirió el ejército en las primeras décadas de vida de México como país independiente.

84 SÁNCHEZ SANTIRó, Ernest, La imperiosa necesidad, 2016, pp. 136-140.

85 Al respecto, consultar: JÁUREGUI, Luis, "Del intendente al comisario", 2001 y "La problemática administrativo-fiscal", 2020. 


\section{Apéndice I. \\ Selección de las "Ordenanzas que corresponden a los comisarios ordenadores y de guerra"}

Año

Ordenanzas, reales órdenes, instrucciones

1705 Real ordenanza de 28 de julio de 1705 para la formalidad de las revistas que los comisarios de guerra han de pasar a las tropas: equipajes, tren de artillería y víveres de los ejércitos, como también de lo que se ha de observar por los tesoreros y asentistas de pan y cebada.

1716 Real orden de 21 de noviembre de 1716 sobre la forma de ejecutar las revistas e intervenir los gobernadores.

1717 Instrucción de 15 de febrero de 1717 para las revistas, que deben pasar los comisarios ordenadores, y de guerra, arreglada por el intendente de Cataluña, en consecuencia, de las ordenanzas de S.M. para evitar los abusos que suelen cometerse en el acto de la revista, y facilitar el más pronto expediente de los extractos de ella.

1735 Real orden de 27 de diciembre de 1735 sobre la intervención que han de tener los comisarios de guerra en los regimientos de milicias.

1737 Real orden de 25 de julio de 1737 sobre que los comisarios de guerra puedan entrar a reconocer los cuarteles y cuerpos de guardia para el arreglo de luces y leña.

1746 Real ordenanza de 27 de noviembre de 1748 sobre el método y orden que han de observar los comisarios de guerra en las revistas que pasen a las tropas.

1749 Real orden de 6 de agosto de 1749 sobre los oficiales comisionados por los cuerpos y el artículo 59 de la ordenanza de comisarios de guerra.

1751 Real orden de 20 de abril de 1751 sobre que los contralores de artillería revisten las tropas del ejército y otras cosas.

1758 Real orden de 3 de julio de 1758 sobre los casos en que ha de asistir oficial interventor a las revistas, y el artículo 22 de la ordenanza de comisarios.

Fuente: Portugués, Colección general, 1765, tomo X, pp. 327-430.

\section{BIBIOGRAFÍA}

\section{Archivos}

AGI Archivo General de Indias.

AGN Archivo General de la Nación.

\section{Fuentes consultadas}

AlBI, Julio, La defensa de las Indias (1764-1799), Madrid, Instituto de Cooperación Iberoamericana, 1987.

AndúJar CASTILlo, Francisco, "El reformismo militar de Carlos III: mito o realidad", Cuadernos de Historia Moderna, 41 (2), 2016, pp. 337-354.

Archer, Christon I., The Army in Bourbon Mexico, 1760-1810, Albuquerque, New Mexico University Press, 1977. 
ArCHER, Christon I., "Bourbon Finances and Military Policy in New Spain, 17591812", The Americas, vol. 37, núm. 3 (enero), 1981, pp. 315-350.

Bertrand, Michel, Grandeza y miseria del oficio. Los oficiales de la Real Hacienda de la Nueva España, siglos XVII y XVIII, Fondo de Cultura Económica, México, 2011.

Borreguero Beltrán, Cristina, "Del tercio al regimiento", Estudis. Revista de historia moderna, núm. 27, 2001, pp. 53-89.

Castro, Concepción de, A la sombra de Felipe V. José de Grimaldo, ministro responsable (1703-1726), Madrid, Marcial Pons Historia, 2004.

Celaya Nández, Yovana, Alcabalas y situados. Puebla en el sistema fiscal imperial, 1638-1742, México, Fideicomiso de las Américas, El Colegio de México, 2010.

Chenaye Des Bois, Aubert de la, Dictionnaire militaire ou recueil alphabétique de tous les termes propres à l'art de la guerre, Lausana y Ginebra, Chez Marc-Mich. Bousquet \& Comp., 1743.

Dubet, Anne, Un estadista francés en la España de los Borbones. Juan Orry y las primeras reformas de Felipe V (1701-1706), Madrid, Biblioteca Nueva, 2008.

Dubet, Anne, La Hacienda real de la Nueva Planta (1713-1726), entre el fraude y el buen gobierno. El caso de Verdes Montenegro, Madrid, FCE, 2015.

Dubet, Anne y Solbes Ferri, Sergio, El rey, el ministro y el tesorero. El gobierno de la Real Hacienda en el siglo XVIII español, Madrid, Marcial Pons, 2019.

EsPinosa Aguirre, Joaquín Edgardo, "Defensa y militarización contrainsurgente en la comandancia de Guanajuato (1813-1816)" (Tesis de maestría en Historia), México, Facultad de Filosofía y Letras-UNAM, 2018.

Esteban Estríngana, Alicia, "Autopsia del despacho financiero. Ejecución y control de pagos en el tesoro militar del ejército de Flandes (siglo XVII)", Obradoiro de historia moderna, núm. 12, 2003, pp. 47-78.

GARriga, Carlos, "Sobre el gobierno de la justicia en las Indias (siglos XVI-XVII)", Revista de Historia del Derecho, núm. 34, 2006, pp. 67-160.

GleseSner, Thomas, L'empire des exilés : Les Flamands et le gouvernement de l'Espagne au XVIII siècle. Nouvelle édition [en ligne]. Madrid : Casa de Velázquez, 2017 (généré le 05 janvier 2021). http://books.openedition.org/ cvz/4082.

Gómez PÉREZ, Carmen, El sistema defensivo americano: siglo XVIII, Madrid, MAPFRE, 1992.

Gómez Ruiz, Manuel y Juanola, Vicente Alonso, El ejército de los Borbones. I. 1700-1746: organización, uniformidad, divisas, armamento, Madrid, Servicio Histórico Militar Museo del Ejército, 1989.

JÁuregui, Luis, La Real Hacienda de Nueva España. Su administración en la época de los intendentes, 1786-1821, México, UNAM, 1999.

JÁUREGUI, Luis, "Del intendente al comisario: la herencia novohispana en la administración fiscal mexicana”, en Ernest Sánchez Santiró, Luis Jáuregui y 
Antonio Ibarra (coords.), Finanzas y política en el mundo iberoamericano. Del Antiguo Régimen a las naciones independientes, México, Universidad Autónoma del estado de Morelos / Instituto Mora / Facultad de EconomíaUNAM, 2001, pp. 223-253.

JÁUREGUI, Luis, "La problemática administrativo-fiscal de un país naciente. México 1821-1824", Estudios de Historia Moderna y Contemporánea de México, vol. 59, enero-junio. 2020, pp. 33-69.

KAMEN, Henry, La Guerra de Sucesión en España, 1710-1715, Barcelona-Buenos Aires, México D.F., Grijalbo, 1974.

KLeIN, Herbert S., Las finanzas americanas del Imperio español: 1680-1809. México: Instituto de Investigaciones Dr. José María Luis Mora/Universidad Autónoma Metropolitana, 1994.

Losa Contreras, Carmen, "La formación de la milicia urbana en la Nueva España", Anuario de la Facultad de Derecho, vol. xxiv, 2006, pp. 177-214.

Moreno GutiÉRrez, Rodrigo, La trigarancia. Fuerzas armadas en la consumación de la independencia. Nueva España, 1820-1821, México, UNAM / Fideicomiso Felipe Teixidor y Monserrat Alfau de Teixidor, 2016.

Nyalor, Thomas H. y Polzer, Charles W., Pedro Rivera and the Military regulations for Northern New Spain, 1724-1729: a documentary History of His Frontier Inspection and the Reglamento de 1729, Arizona, University of Arizona Press, 1988.

Ogelsby, J. C. M., "Spain's Havana Squadron and the Preservation of the Balance of Power in the Caribbean, 1740-1748", The Hispanic American Historical Review, vol. 49, núm. 3, agosto de 1969, pp. 473-488.

Ordenanzas del Ejército para su régimen, disciplina, subordinación y servicio, dadas por Su Majestad Católica en 22 de octubre de 1768. Reimpresas de orden del Gobierno de Venezuela por la primera edición real de Madrid de 1768, Caracas, Imprenta de V. Espinal, 1841.

Ortiz Escamilla, Juan, Ordenanzas Guerra y gobierno. Los pueblos y la independencia de México, 1808-1825, México, El Colegio de México / Instituto Mora, 2014.

PÉREZ ESPINOSA, Anaximandro, "Contrainsurgencia en el sur y rumbo de Acapulco (1814-1820)" (Tesis de maestría en Historia), México, Facultad de Filosofía y Letras-UNAM, 2018.

Pietschmann, Horst, Las reformas borbónicas y el sistema de intendencias en Nueva España. Un estudio político administrativo. México, FCE, 1996.

Portugués, Joseph Antonio, Colección general de las ordenanzas militares, sus innovaciones y aditamentos, dispuesta en diez tomos, con separación de clases por..., Tomo X, Madrid, Imprenta de Antonio Marín, 1765.

Rabinovich, Alejandro, "La militarización del Río de la Plata, 1810-1820. Elementos cuantitativos y conceptuales para un análisis", Boletín del Instituto de Historia Argentina y Americana "Dr. Emilio Ravignani”, Tercera Serie, núm. 37, segundo semestre, 2012, pp. 11-42. 
Real Academia de la Lengua, Diccionario de la lengua castellana compuesto por la Real Academia española, reducido a un tomo para su más fácil uso, Madrid, Por Don Joaquín Ibarra, 1780.

Real ordenanza para el establecimiento e instrucción de intendentes de ejército y provincia en el Reino de la Nueva España. 1786. Estudio introductorio por Ricardo Rees Jones, México, UNAM, serie facsimilar, 1984.

Reglamento e instrucción para los presidios que se han de formar en la línea de frontera de la Nueva España. Resuelto pro el rey Nuestro señor en cedula de 10 de setiembre [sic] de 1772, México, Oficina de la águila, dirigida por José Ximeno, 1834.

Reglamento y ordenanzas para el presidio de la Veracruz y castillo de San Juan de Ulúa, expedido por el Excmo. Señor marqués de Casafuerte, capitán general de los ejércitos de S.M., su virrey gobernador, y capitán general de esta Nueva España, y presidente de la Real Audiencia y Chancillería, que en ella reside, México, Imprenta de los Herederos de Miguel de Rivera, 1727. SÁnchez SANTIRó, Ernest, "La Hacienda reformada: la centralización de la renta de alcabalas en Nueva España (1754-1781)”, en Ernest Sánchez Santiró, Luis Jáuregui y Antonio Ibarra (coords.), Finanzas y política en el mundo iberoamericano. Del antiguo régimen a las naciones independientes, México, Universidad Autónoma del Estado de Morelos/Instituto Mora/facultad de Economía-UNAM, 2001, pp. 143-177.

SÁnchez SAntiró, Ernest, Corte de caja. La Real Hacienda de Nueva España y el primer reformismo fiscal de los Borbones (1720-1755). Alcances y contradicciones. México, Instituto Mora, 2013.

SÁnchez SANTIRó, Ernest, "Antonio de Medina y Miranda (1777-1821): la deuda pública y la paráfrasis de Adam Smith", en Ernest SÁNCHEZ SANTIRó (coord.), Pensar la Hacienda pública: personajes, proyectos y contextos en torno al pensamiento fiscal en Nueva España y México (siglos XVIII-XX), México, Instituto de Investigaciones Dr. José María Luis Mora, 2014, pp. 73-92.

SÁnchez SAnTiró, Ernest, "El gasto público de la Real Hacienda de Nueva España durante el siglo XVIII: estructura, dinámica y contradicciones", en Ernest Sánchez Santiró (coord.), El gasto público en los Imperios ibéricos. Siglo XVIII, México, Instituto Mora, 2015, pp. 73-126

Sánchez SAnTIRó, Ernest, La imperiosa necesidad. Crisis y colapso del Erario de Nueva España (1808-1821), México, Instituto Mora / El Colegio de Michoacán, 2016.

SÁnchez SANTIRó, Ernest, Documentos para la historia fiscal del Erario de Nueva España (1808-1821), México, Instituto Mora, 2017.

SÁnchez SANTIRó, Ernest, "El aprovisionamiento de las fuerzas de defensa continental del reino de Nueva España y sus provincias adyacentes: el caso del sistema de habilitados castrenses", en Rafael Torres Sánchez (ed.), Studium, magisterium et amicitia. Homenaje al Profesor Agustín González Enciso, Pamplona, Ediciones Eunate, 2018. 
SAnZ, Raimundo, Diccionario militar, o recolección alphabetica de todos los términos propios del Arte de la Guerra..., Barcelona, Imprenta de Juan Piferrer, 1749.

Serrano Ortega, José Antonio, Jerarquía territorial y transición política. Guanajuato 1790-1836, México, el Colegio de Michoacán / Instituto Mora, 2001.

TeIJEIRo DE LA RosA, Juan Miguel, "La Hacienda militar en el siglo XVIII", en Centro Superior de estudios de la Defensa Nacional, VII Jornadas de Historio Militar. De la Paz de París a Trafalgar (1763-1805). La organización de defensa de la monarquía, Madrid, Ministerio de Defensa - Secretaría General Técnica, 2003, pp. 83-104.

TorRes SÁNCHEZ, Rafael, "La «militarisation» des finances royales d'Espagne au XVIIIe siècle", en Anne Dubet y Jean-Philippe Luis (dirs.), Les financiers et la construction de l'État. France, Espagne (XVIIIe-XIXe siècle), Rennes, Presses Universitaires de Rennes, 2011, pp. 177-198.

TorRes SÁnchez, Rafael, La llave de todos los tesoros. La tesorería general de Carlos III, Madrid, Sílex, 2012.

Este trabajo ha contado con el apoyo del "Proyecto Apoyado por el Fondo Sectorial de Investigación para la Educación" SEP-CONACYT ("Gobierno y administración de la Real Hacienda de Nueva España, siglo XVIII”, proyecto A1-S-18810).

Esta obra está bajo licencia internacional Creative Commons ReconocimientoNo-Comercial-CompartirIgual 4.0.

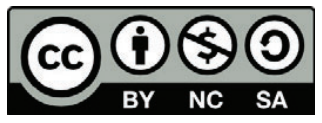

